\title{
7.Arts journalism and exiled writers: a case study of fugal, reflexive practice
}

\section{ABSIRACI}

Arts journalism and reflective practice intersect in a new field of 'journalism as research' (Bacon 2006). This article takes an innovative approach informed by the multimodal, musical and psychogenic fugue to discuss a case study of arts journalism reflexive practice. The journalistic research topic is the impact of the traumatic journey of exiled writers on their creative writing, the empathetic effects of trauma and courage on their advocates and the impacts of researching trauma on the researcher. The journalistic, interview-based articles discussed in the case study are on exiled writers in Australia, Iranian poet-musician Mohsen Soltany Zand and Ivory Coast political journalist Cheikh Kone. In reflecting on processes of writing of the stories, the author begins to outline the foundations of an innovative, critical fugal methodology of reflexive practice for modes and pieces of arts journalism.

Keywords: arts journalism, creative writing, exiled writers, fugue, multimodality, trauma

\section{RUTH SKILBECK}

\section{University of Technology, Sydney}

RTS journalism as reflexive practice is a relatively new, yet
significant and developing trend, as journalism increasingly finds
its way into the university curriculum (Bacon, 2006). The purpose of this article is to discuss a project of arts journalism as reflexive practice. The topic of reflection is an arts journalism research project that set out to interview exiled writers, and publish a journalistic story, with the purpose of reflectively critiquing this process. This research, which began its life with the working title 'Refugee Writers: Beyond Detention' was supported by a grant from the Australian Centre for Independent Journalism. The main field 
work included locating and interviewing exiled writers and their advocates, in Australia, between 2007 and 2008. Two journalistic articles were published based on interviews with exiled Iranian poet-musician Mohsen Soltany Zand and former Ivory Coast political journalist Cheikh Kone.

A parallel aim of the research was to experimentally apply an innovative methodological approach based on research into the multimodal form of fugue (with dual musical and pyschological meanings). As an arts writer and researcher, I have been researching what I term the 'fugal modality' in various modes and genres of arts writing for over 11 years. With this aim, the paper suggests and tests a few fugal critical style terms, or techniques, for reflexive practice. For example, the discussion demonstrates what I term 'fugal recursion' - the practice of 'putting on hold' thematic variations whilst the composer concentrates on developing one voice, or section of articulation, in the multimodal process of writing as creative art. I suggest that this is an apt (reflexive) analogy for the process of reflective practice from the perspective of the practitioner as creative artist/critical author/arts journalist.

The reflexive inquiry has three main interwoven strands evoking comparison with a three part fugue that occurs through the counterpoint of its interweaving 'voices'.

The first voice — or strand - of the inquiry, is the plan of the project. The starting themes, articulated in the proposal for the research into how exiled (refugee) writers who have been through the trauma of exile followed by detention have fared after being released from detention into Australian society as citizens.

The research plan had several interwoven aims, inquiring into:

- How have experiences of exile affected the writing of writers exiled for their writing?

- How does communication with the exiled writers mutually affect the lives of those who seek to assist them?

- To give a speaking voice and human presence to exiled writers in the media dialogue over the treatment and reception of political refugees of war.

- To research the growing social movement comprising dialogue and cross-cultural exchange through conversation, poetry and writing between exiled writers, their advocates, readers and supporters.

The second strand of inquiry was into the processes of journalistic 
writing and publication of such a research inquiry; how would I write the story and where would I publish it? As an arts writer specialising in contemporary art, this seemed to be a different field and 'market' to the art periodicals that publish art criticism and journalism, although there were overlaps. Although not always the case, writing about and by, exiled and writers and artists tends to be positioned at the extreme end of Bourdieu's 'autonomous pole' of journalism (Bourdieu, 2005; 2003) although some market-focused art periodicals may be closer to the 'heteronomous' pole (ibid).

The third strand in the inquiry is that of reflexive practice in journalism, the meta-layer of critical reflection (practised herein).

\section{Reflexivity: a fugal approach}

The term reflexivity as a mode of research developed in social science to 'refer to reflectiveness amongst social researchers about the implications of the social world they generate of their methods, values, biases, decisions, and mere presence in the situation they investigate' (Bryman, 2004, p. 543). Reflexivity in creative writing means that writing is unconsciously and cons ciously shaped by - and performatively articulates - the author's values, biases and intentions. In her paper 'Journalism as Research?' (2006) Wendy Bacon discusses reflexivity as a mode of inquiry with relevance to journalism research in contemporary Australia. One of the current critical issues is to do with the aspect of reflexive practice known as 'diarising'. Whereas Bourdieu criticised this practice, Wendy Bacon is supportive, seeing this as a way to avoid a problem in journalism studies of objectifying journalism from the outside, rather than approaching research, from within. 'Some form of diarising, reflective journal or interrogation of the process of investigation may be a way of closing the gap...' (Bacon, 2006, p. 155). I agree with Wendy Bacon on this. In this paper I interweave aspects of theory and practice, as a starting point for a multimodal (van Leeuwen, 2001), fugal, critical analysis.

Bourdieu emphasised the reflexive importance of awareness of the researcher's habitus - the framework of beliefs, attitudes and ideologies that she brings to her research. In the context of reflexivity, the fugal, multimodal methodology I develop and apply here is analogously informed by the dialogic, polyphonic musical form of the fugue and contextually informed by my professional and research experience as a feminist art critic, independent arts writer and researcher. 
Bourdieu's development and application of a notion of reflexivity in his research was relational. (The fugal approach developed here draws on notions of relational aspects in social and cultural theory). Bourdieu's analysis (eg. in Bourdieu \& Wacquant, 1992) emphasises relationship forces (power relationships in the 'game' of field theory). This is how a fugal analysis may interpret its 'data': in terms of the power, or force of the voices, quoted and/ or referenced in a dialogic discourse, or articulated in a genre text (such as journalistic article) or in terms of their relationship to each other of dominance, subordination, marginalised voices in a dominant, mainstream media discourse and so on. Such an analysis is developed by Kristeva, influenced by Bakhtin, in her theories of subversive 'carnivalesque discourse' (Kristeva, 1986 ; 1974) and by feminist art historians, such as Linda Nochlin's work on art history, gender and power (1994).

Fugue analogies, in various interpretations, have played a significant if subliminal role in the development of methodologies of contrapuntal cultural interpretation, including Edward Said's (1993) contrapuntal reading, Bakhtin's (1981; 1965/93) polyphony and dialogism, Bhabha's (1994) cultural hybridity, influencing the writings of écriture féminine and feminist postFreudian psychoanalytical theory by Kristeva (1974; 1982) Cixous (1991) Irigaray (1977) and Klein (1930); all of which has informed the fugal methodology I develop and apply here.

The fugal modality is a form of multimodality, a new critical research field pioneered by Theo van Leeuwen (van Leeuwen \& Kress, 2001) that positions the construction of meaning as an assemblage of multimodal, sensory, perceptual and conceptual elements; the fugal modality is based in sensory perception in the body.

As a methodology, fugal modality reflexively produces meaning that is dialogic, polyphonic and intertextual. The fugue is a cultural figure with seemingly paradoxical meanings. As a musical form, the fugue interweaves many voices, in infinite inventive variations on a theme, with its origins in the singing voice of antiquity and the circular 'round.' Whereas the fugue reached its apogee of spectacular refinement and complexity in the Baroque era, in one form it is a simple, circular melodic 'discourse' that evolved in communities and households, in which, hypothetically, anyone can join. In my interpretation, the fugue symbolically and literally, enacts a democratic, non-hierarchical form for infinitely many, and diverse, voices - a form of cultural conversation that follows 'rules' coded and constructed reflexively 
by the 'melody lines' which each participating voice takes up, interpretively playing variations on the theme. It is therefore a useful arts-based analogy for expanding cross-cultural conversations for many voices in the mediated, globalising world.

Fugal critical style terms (Skilbeck, 2007) may thereby have affective echoes, whose exact meaning and nuance will depend on the interpretation of the reader. These are a few that I use-after recounting how the stories were written - as the starting point of a critical analysis, to be continued in and developed in further research:

- Fugal modality of writing-on multimodal form of creative 'dissociation' and freedom of expression that, paradoxically, includes the writer (artist/author) as a creator of the meaning of the text she composes

- Fugal recursion - (as referred to earlier)

- Polyphony - many voices

- Counterpoint - interweaving of 'voices' (not necessarily oral, a visual image or effect can be a 'voice')

- Double counterpoint - relational aspect of force implied, as in carnivalesque parodic satirical discourse or dialogue (Kristeva, 1974;1986)

- Dialogism -Bakhtin's (1981) term for the interplay and intertextuality of voices in cultural productions.

Drawing on Skilbeck (2005), the fugue's second 'psychogenic' meaning as a wandering journey of temporary self-loss also has resonance in this analogy. As a way of referring to processes of writing that operate on an unconscious level, driven by deep psychic movements of dream, trauma and desire. Exploring the unconscious function of writing as a form of restitution of a lost object (Klein, 1930/1975), that paradoxically entails a form of dissociative self-loss in which the 'subject' writes to reconstitute the Self, is a rich field for inquiry. Contemporary trauma theories (Skilbeck, 2007; Caruth, 1995;1996; Sztompka, 1993) suggest a link between trauma and creative innovation-as a form of self survival. Sociologist Jeffrey Alexander (2004), links cultural trauma to the formation of collective or group identity through subliminal strategies of empathetic inclusion or social exclusion. Literary theorist Susan Gubar $(2003 ; 2004)$ explicitly connects certain forms of non-representational (fugal) poetic and trauma in her work on holocaust poetry. 
Researching exiled writers stretches the fugue approach to social and cultural extremes, where the meaning of flight takes on a profound resonance in relation to deterritorealisation of the global media. The exiled writers took flight physically from their homelands to save their lives then took flight metaphorically in their writing in the detention centres. For example, as I discuss soon, in detention, Cheikh Kone created a newspaper that he called Freedom, which was sent into the outside world. Their writing, for which they were exiled and imprisoned, eventually helped secure their release.

Displaying further aspects of fugal border crossing, the two articles discussed here are written in distinctly different modes and styles. The first is a 750 word arts-based story, 'Make Art Not War' (Skilbeck, 2008) using an innovative multimedia modality of writing, interweaving artworks, photographs, poetry and imaginative written text, based on interviews with Mohsen Soltany Zand and published on the new media news and arts website, Homepage Daily, in early February 2008. The second story of approximately 2500 words was also published on World Press Freedom day on 3 May 2009 in Homepage Daily. In this story, which is written in an objective factual reportage style, exiled Ivory Coast journalist Cheikh Kone tells his story in his own voice. I briefly discuss in the next sections how these modes came to be chosen in the context of the research, and what these differences may articulate in a wider cultural and social sense.

\section{Research in a field of trauma}

Amongst the specific conditions this assignment brought in its preparation and design, were the special requirements of researching and interviewing in a field of trauma. As a guide for preparing interview questions I consulted recent, updated codes of ethics issued by two journalist unions: Australia's Media Entertainment and Arts Alliance (MEAA), and the United Kingdom's National Union of Journalists (NUJ), which has published 'NUJ guidelines on race reporting' and 'Reporting Asylum and Refugee Issues' (2008). It was important to the aims of the project to give the writers the opportunity to speak freely for themselves. I did not know if any of those with whom I made contact would be able to speak English and was expecting to employ a translator, which turned out not to be necessary. I formulated open questions that would allow the interviewees to speak about themselves, their experiences and their writing with minimal pressure or obtrusive prompting. 
This meant following principle of ethical interviewing, avoiding leading and closed questions that might 'put words into their mouths'.

I decided to ask the same set of questions to all the exiled writers, beginning with the opening question:

This has been a long journey, exile, migration, detention and finally being freed in Australia. How have these experiences affected your writing and how has your perspective as a writer shaped the way these experiences have affected you?

My strategy in devising open questions was to allow the writers to talk at length and at tangents, at their liberty.

With the advocates' and activists' questions, I wrote each set of questions tailored to the person I sought to interview and the information I wished to gain from them. This was mostly about their own experiences and how working in this field and their contact with the writers had affected them. It was a significant part of the research proposal:

[T]his research shall also look at the writings of the refugees in terms of the (polyphonic) dialogue with the poetry of the people who are advocating for them.... This exchange constitutes a social movement of cross-cultural communication: creating a new form of fugal poetic literary communication in contemporary Australian society [Information gained from reading, observation and Sydney PEN, March 2007]. (p. 133)

\section{Exiled writers' stories}

A main starting point for contacting people to interview was an anthology of writings by exiled writers, Another Country (2004), edited by Australian novelists Rosie Scott and Thomas Keneally, published by Sydney PEN (Poets, Essayists, Novelists), the UN-sanctioned international writers' advocacy group, and Halstead Press. It comprises stories, play scripts, poetry and short texts by 22 writers. At the time of writing, they were all asylum seekers in detention in Australia. The book helped to secure the release of many of the writers as legitimate political refugees (Skilbeck, 2009).

In one of the first contacts made in this research journey, I spoke via email with Denise Leith, author of Bearing Witness: the Lives of War Correspondents and Photojournalists (2004) and a member of the PEN 
Writers in Detention Committee. The research journey lasted for over one year, including field trips to the Newcastle Young Writers Festival 'Writing and Censorship' panel organised by Sydney PEN, at which Mohsen and others spoke, poetry reading events in Sydney, and a visit to Villawood Detention Centre, in Sydney's west.

Each of the exiled writers I interviewed fled their undemocratic homelands, because their life was endangered by their writing. On arrival in Australia, Mohsen spent four years, and Cheikh three years, in immigration detention centres, before lobbying by Sydney PEN Writers in Detention Committee helped secure their release.

\section{Mohsen's story}

An advocate who had visited him in Villawood, and remained good friends with him, introduced me to Mohsen Soltany Zand. I accompanied him to a spoken word poetry event at Bar Me, a basement bar in Kings Cross. Mohsen was performing spoken word poetry and playing improvised music accompanied by two men on traditional Persian instruments including sitars. Mohsen agreed to my request to photograph him as he spoke and to an interview.

I interviewed Mohsen twice at his home in inner Sydney. He told me about the trauma that he had experienced and how this had affected him. Even though he had been released three years before, under medical advice, he still could not work full time. He was finishing a surveying course at TAFE. He had fled Iran after exposing corruption: 'For my political activism I became endangered. I came to Australia by plane to Perth.' He had thought that he was going to Perth in Scotland. When he arrived he was put into Port Hedland Detention Centre, then moved to Baxter Detention Centre. He said: 'There were five people to a [small] room with two beds...if the door opened [it] banged you on the head.' Following a protest, detainees were sent to a prison for a few months. In comparison, he said: 'When I went to prison it was wonderful. Everything was good. The doctor we could see. In 18 months I hadn't seen any doctor, any specialists. I was in a very, very bad condition.' After three years he was transferred to Villawood, in western Sydney.

The article I wrote after speaking with Mohsen, 'Make Art Not War', is a piece of experimental arts writing. I wrote it in the 'voice' of Rosa Viereck, art critic and abstract expressionist artwork, in a column that I entitled Pink Oblong (Rosa Viereck is the title of a painting by Vasily Kandinsky). Yet the story is clearly ascribed to the author in a copyright attribution at the end 


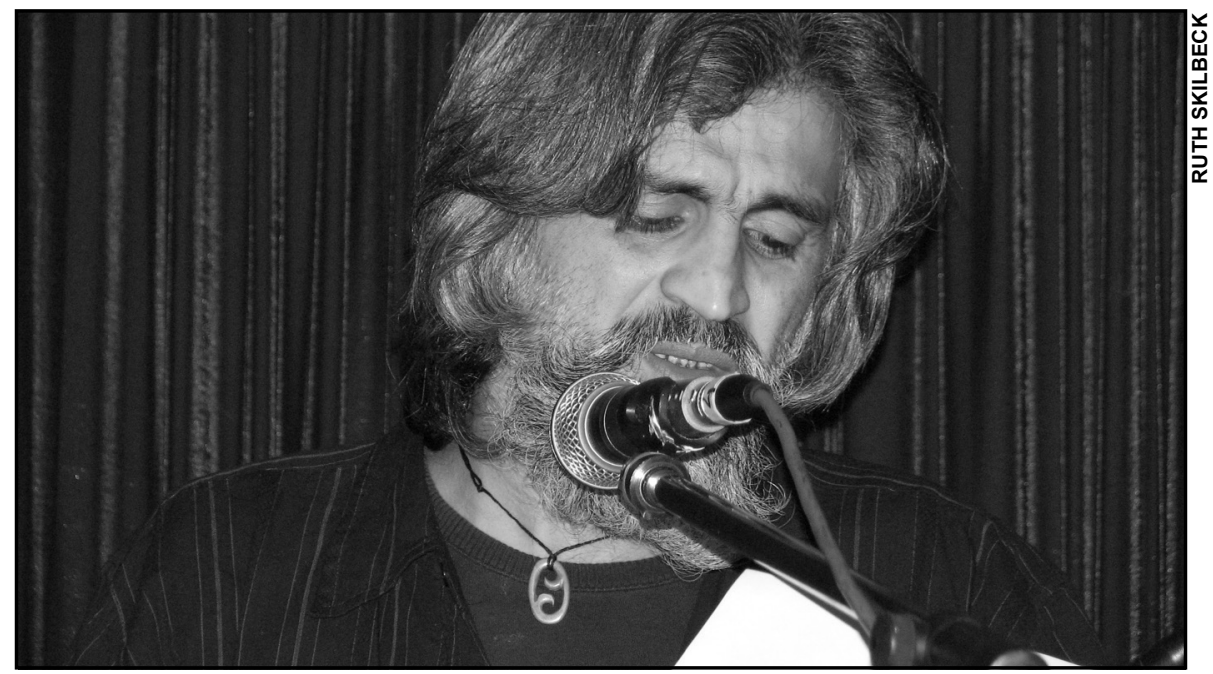

Figure 1: Exiled Iranian poet-musician Mohsen Soltany Zand giving a reading at Bar Me, Kings Cross, Sydney, September 2007.

of the story. The multimodal story also included a photo I took of Mohsen reciting poetry at Bar Me.

Why did I take this approach? I was affected by Mohsen's story, by the anguish of his poetry. This drove an attempt to inhabit more deeply the imaginative and affective space that Mohsen described in his poetry, his conversation, and his music. Visually, I saw this space - of trauma, isolation and displacement - in the paintings of Sydney Nolan in a retrospective of his works at the Art Gallery of New South Wales at that time. I heard it in the words of indigenous speakers on Human Rights Day. I wove the threads together in an abstract piece on cultural trauma and identity on Australia or Invasion Day. The article was published with photographs I took, and an image of Nolan's Ned Kelly painting.

The story began:

Australia, or Invasion, Day, makes me think of geometric shapes. Black squares. White cubes. Me. In a gallery. A pink oblong. My own shape. Rosa Viereck: pleased to meet you. (Skilbeck, 2007)

The abstract, fragmented voice continues:

I'm secure in my identity. But sometimes just the sound of the word Australia, let alone its abstraction, can make me question who I am. 
'Where do we come from? What are we? Where are we going?' was modernist artist Paul Gauguin's heartfelt cry in 'French' Tahiti. His painting's plea becomes an epithet to colonial identity confusion. (ibid.)

Interweaving, in a multimodal fugue:

I am looking at the symbolic shape of what is known as an icon of Australian identity art. Sidney Nolan's outlaw: Ned Kelly. Riding through a desert. Gun in hand. In reverse. A symbol of quixotic alienation: human form reduced to a black abstraction in the red heart. White settler alienation in a black helmet. What are we? What does it mean to be Australian? It's a familiar refrain. Can we find ourselves through Art? I am here to tell you, yes, and lose ourselves as well. Look at me! And look at Nolan ...

The dissociated voice of Rosa Viereck, Pink Oblong, abstraction personified, linked together unsettled Australian artists, indigenous women activists and exiles in detention in the desert:

Looks like he found out a thing or two as he lost himself in a hallucinogenic landscape of his own perception. About the shifting shapes of 'settler' identity. The outlaw. The colonial law enforcers.

The voice stops and starts; breaks and continues:

But things have changed since Nolan painted his Kelly series in the late 1940s. The modern era has shifted to postmodernism. Multiplicity abounds. Polyphony rocks. In the new era of protest, outlaws are replaced by activists. Fighting for social justice for outsiders 'othered' by the ex-colonial law makers. Refugees in detention. Indigenous communities. Stranded in 21 st century deserts. Deprived of health and education services settler society calls basic. When activists faced charges - later dropped - of helping refugees escape the country to a third country of refuge, writer and refugee supporter Tom Keneally wrote to those facing court: 'The better angels of Australia are singing with you.' (ibid.)

The story was intertextual, quoting from an art work and from:

My new favourite book. Another country: writers in detention, edited 


\section{PUBLIC RIGHT TO KNOW}

by Tom Keneally and Rosie Scott. I open at random, and read:

In the midst of parched desert

No one can come with us

We cannot journey hand in hand

There is no green place to rest the eye

And the scorching wind of destiny lashes at our backs A call to DIMIA is like the smell of rain in the desert Hope, like black clouds, building in our thirsty hearts Turns quickly to grief

The deconstructed narrative ended with an exhortation:

In the great southern land we are all at heart dislocated, invaded and invaders. Together, we can reshape the future. Through mutual acceptance of many colours and shapes. Reconciliation. Make Art not War. (Skilbeck, 2007)

\section{Cheikh Kone's story}

The second article drew on a long interview with Cheikh Kone. The article was written in a more conventional style of reportage, whilst allowing maximum space to quote his story, and views, that he relayed to me in our recorded interview. I contacted Cheikh initially by telephoning his work place; he is a field officer for a union in Canberra. A couple of weeks later he was in Sydney. I interviewed him at the University of Technology, Sydney, where I was working, and where he had gained his law degree.

He told me that at Port Hedland detention centre he and some other inmates started a newspaper.

'We had a committee management that said we could have a newsletter. We were allowed to have a computer at least a couple of hours every day so we started a little newspaper called Freedom. We did only three issues, once a month.'

But, he says: 'The second issue, I got called up in the director's, the immigration, the manager of the detention centre in his room. He told me that my writing was too gloomy. That that wasn't a good thing for this place.' They wanted him to write humorous articles. 'And I said: well, like there's nothing funny to write about in this place, this is probably the saddest place I've ever seen. We're finding young kids and 
women sitting there doing nothing with their life apart from getting depressed. So they said: well, if you don't, we won't allow you to write. (Skilbeck, 2008)

He continues his story:

But [meanwhile] with the first issue, and with the second, people who got their visas were leaving and I smuggled a copy out so people could read it on the outside. I faxed a couple of copies to Amnesty International overseas... I decided, okay, I want to keep on writing so I started to write a poem: on the door of my room, on the wall, on the ceilings. I just wrote everywhere, and there were things from political speeches from Nelson Mandela or Luther King, talking about freedom basically... just to let them know that, yes, I

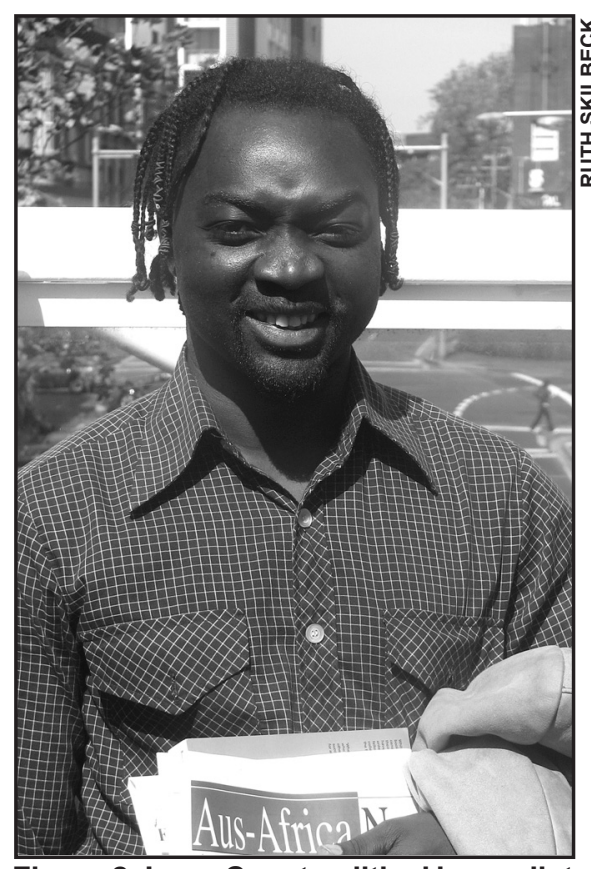

Figure 2: Ivory Coast political journalist Cheikh Kone, publisher of the detention centre publication Freedom. do still believe what I mean, I just want to make sure that other people know that it's okay to be free like this is not utopia, we people can be free. I did a lot of writing, like pasted on my wall, and everywhere I could basically. Some Australian people [from outside] got involved knowing what we are doing and I asked for and I got my own computer, and so then I started to write a story...'

He spoke of how these experiences had affected him and his writing:

'That's really hard to say because I think my view of the world has changed, which means my way of writing would have changed in the sense that I believed in that democratic ideal that I always believed that democracy would do the right thing by its people, the system is flawless, people will always pick the right leaders and those who are elected will be fair to people. And if there's an outcry, there's a decision they don't want it to happen. But being here for me well my view of democracy 
has changed and that has also changed my way of writing...it changed me in the sense that I wouldn't say I've become an anarchist but I'm really disappointed in this whole system.' (Skilbeck, 2008)

The long article was based around an extended transcription of Cheikh's story in his own voice.

\section{Trauma and its cultural effects on advocates}

In an interview with Rosie Scott in an inner city Sydney cafe I asked her about her role in setting up and running the Writers in Detention Committee and about how her experiences as an advocate for exiled writers had affected her own writing. She said that she had just had the idea to write a new novel when she was asked to join the advocacy movement. This was to prove so all absorbing and time consuming that she 'lost' her own embryonic novel in the ensuing years of advocacy.

She said: 'there was a huge grassroots [activist] movement in Australia, it was wonderful. The first time I went to Villawood I was so shocked by it, that's where I got the title for it [Another Country]; they were kept there for years. It was like a little concentration camp.' She talks of the writers: 'All of them have gone on to lead very creative lives- the determination that got them to Australia, it's a wonderful testimony to their spirit and courage. They probably have nightmares. They were intelligent and articulate. They could write; they could express their trauma, I know of people who had nervous breakdowns, some because of that [not being able to express their trauma]. They're people with a high amount of determination, to still have a very strong political awareness, and compassion and courage.'

After years of advocacy, for which Rosie Scott and Thomas Keneally were nominated for Human Rights Awards, the long term stress of refugee advocacy affected her health: 'I developed chronic fatigue syndrome like many advocates. Therefore I have stopped.' Although, she adds, she is writing another novel.

Talking to Rosie gave me an insight into the high levels of stress and trauma experienced not only by the exiled writers but also by those who became involved in helping them. My interview with Rosie Scott occurred after my first meeting with Mohsen at his poetry performance at Bar Me, and before the interview with him. My interview with her prepared the way for 


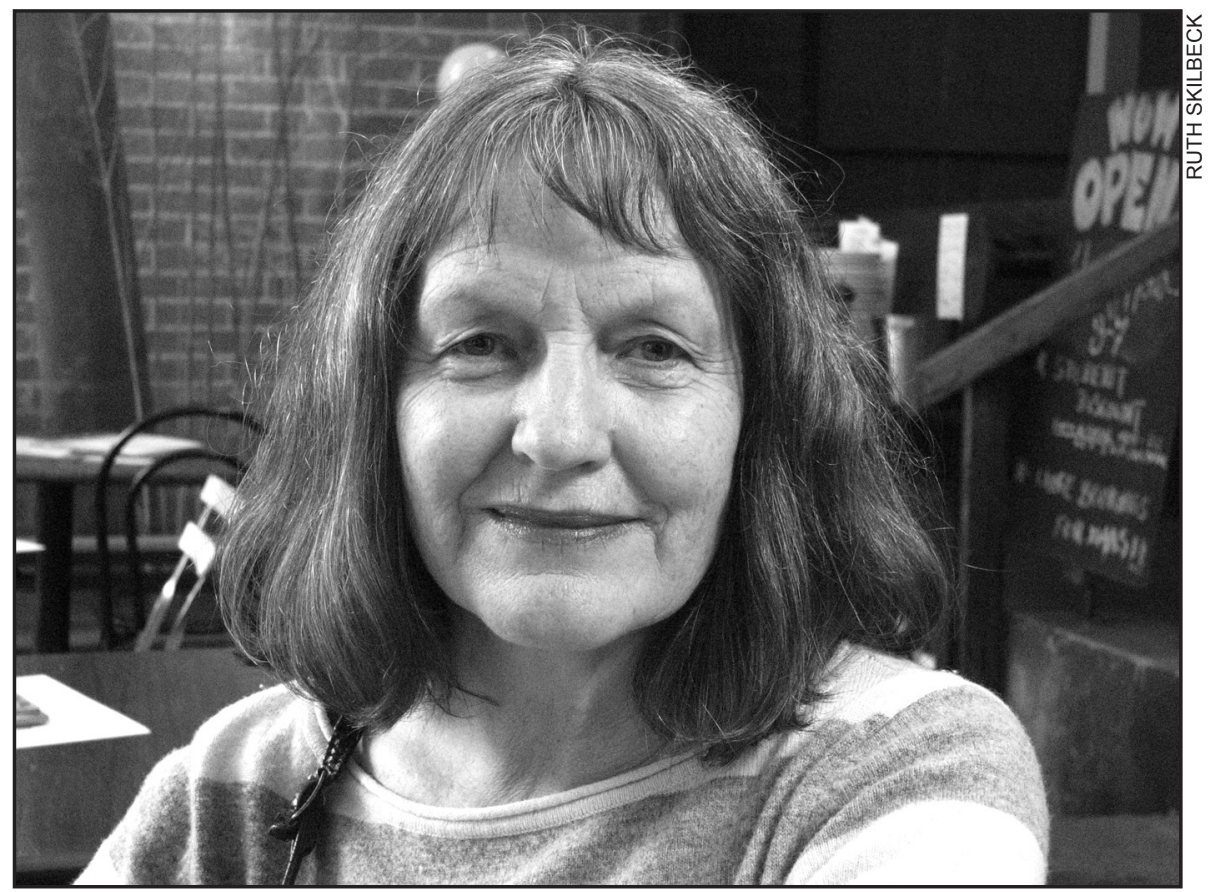

Figure 3: Exiled writers advocate Rosie Scott at Café Otto, October 2007.

my interviews with Mohsen and later, Cheikh Kone. Talking with her gave me an idea of what to expect.

My way of approaching the writers was a gradual process. I made contact with respected writer-activist Denise Leith, who led me to Rosie Scott. Rosie, who was good friends with Mohsen and Cheikh, had maintained contact and support with each throughout their difficult journeys into their new lives as Australian citizens. In finding my own way through the journey of this research, my initial contacts with members of Sydney PEN's Writers in Detention Committee was a catalytic introduction.

\section{On writing the journalistic stories: A fugal critical analysis}

The two articles are markedly different in their story telling mode. The first was intentionally written in another voice - that of an abstract art work-a parodic persona that at first sight ironically demonstrates the 'disappearance' of the author; the various modes invite additional interpretations by a reader. However, it is in this voice that the author's voice is most strongly realised, 
performatively demonstrating a fundamental paradox of authorship, that the voice of the author in the text is separated from the author as living being. This can also be seen as a performative way of manifesting a response to trauma through dissociation. In this way, the writing literally manifests and performs a fugal modality of writing in which the writer loses awareness of her identity and wanders off on a journey into the unknown. This story was researched in the months before the election that voted out the Liberal-Coalition government that had brought in one of the most stringent immigration detention systems in the world. The Labor government's election promise to rescind the controversial 'Pacific Solution' was considered by some media and political commentators to have contributed to Labor's election win (Marr, 2009).

To be writing about such issues brought a feeling that courage was required to tell the stories of the courageous. In disguise, yet perhaps also reaching more deeply into the heart of the experience of exile and dislocation, and finding within that fractured heart a paradox, that the sense of dislocation that if we are brave enough to admit it, is what we all share; that we are united in our difference by acknowledging and that a new stronger collective identity may be formed.

The second story was written over one year later when, as many commentators observed, what at times resembled a climate of fear in Australia (Keneally \& Scott, 2004) had transformed into one where freedom of speech once again felt like a basic right (Marr, 2009).

\section{Fugal critical style terms}

Applying fugal critical style terms, there are numerous 'fugal' moves that may be interpreted and analysed in the writing of the stories. Each is interview-based yet each is written in a very different 'voice', or voices. The first is experimental and performative, the second is pared back and direct.

The first story is the more fugal of the two; in terms of writing style and content this story embodies the fugal modality of writing. The writing style is innovative and language based and musicalised. The 'voice' of the text is significantly dissociated from the author. The story is carnivalesque, exhibiting modes of parody, satire driven by a deeper sense of social injustice, and clearly articulated effect of trauma. Interwoven through the written text are striking modes, or 'voices' of visual communication: images of art work 
and photographic portraits. Fugal recursion occurs in the 'putting on hold' of one voice (written text) while another voice (visual communication) interprets the theme in a different way. This creates a counterpoint of voices. The double counterpoint occurs in the parodic, subversive, intertextual modality of interdiscourse. The story's dialogism operates on several levels of cultural, social, political, historical and art historical discourses.

In the second story, the elements of a fugue analysis are open to interpretation, and phenomenological experience. A fugal interpretation of analysis can be given in a re-writing of the events of the interview encounter. The fugue may be interpreted to include elements of non-verbal communication in the dialogic, performative encounter of the interview. The fugue of the dialogic exchange comprises the look in Cheikh's eyes, the tone of his voice, certain hesitations and accelerations; when he says 'It is a long time since I have spoken of such things'. Or 'I never usually talk of this.' An intensity of wordless gestures. A poignancy and strength. And grace of spirit, expressed through the language of the body, in the time of the interview. As well as the fugal experiences of exile that are verbalised.

\section{Exile and freedom}

There are further stories to be drawn from the case studies. Stories that speak of how writing and story-telling may be unconsciously affected, impacted and shaped, by the experiences of the writer, in (not necessarily conscious or intentional) response to the social and cultural contexts in which she or he writes. This is reflected in ways that Mohsen Soltany Zand's and Cheikh Kone's, writing changed according to their life experiences and contexts.

Each wrote in their first languages (respectively French and Farsi) in their homelands: political writings driven by their passionate belief in democracy. Later, in Australia, their writing was for each of them a life line in the 'hellish limbo' (Skilbeck, 2009) of the detention centres. Writing literally manifested Freedom for Chiekh Kone. For Mohsen, it was writing his poetry that kept him sane. Their writing was their first mode of communication with others, the citizens from outside who built up and maintained the connections through writing letters (Keneally \& Scott, 2004). For each of these writers - and for others in detention centres it was their writing - which had caused their loss of freedom in a material sense, that was also their pathway and connection to a new life. 
Each in different ways, used their writing to help others find freedom. Mohsen made two CDs of his poetry and music-with leading Australian artists. All proceeds from the sales went to Chilout, the movement that lobbied to end the detention of children.

Each continues to uphold the freedom to write. And yet, on leaving detention, there have been changes in their writing. This speaks of the deep driving unconscious purpose of a certain kind of writing. Writing as a lifeline to articulating the Self in the most extreme circumstances of alienation in modernity. This has driven much of the most innovative and profound literature - including journalism - written in modernity. The profound need to write - to 'speak truth to power', to enlighten a community, to express oneself - continues to drive writers in their quest for freedom of expression and to construct a more equitable world where social justice prevails.

\section{Coda: Writing of the fugue of exile}

And how did the research of writing these journalistic stories affect me as a researcher and writer? I found the political, human rights aspects of the research challenging. I had been expecting, and was to an extent prepared, for the traumatic experiences of the exiled writers. Finding out the scale of the traumatic experience, stress and struggles of the advocates was unexpected. As an individual researcher and writer, I felt challenged to be working in this field. Although this was counter balanced by the knowledge that the project was guided by higher motives, that went beyond me as an individual. Belief in a shared humanity, in freedom of expression, and the human rights of the writer and artist committed to humanitarian principles and democracy. Ultimately, however, inquiry into political and social activism was not what drove the research; this was experience and knowledge acquired on the journey. What drove and sustained the project was commitment to inquiry into the writer's fugue and the fugal modality of writing. Not so much as a historical literary form but as a modality of creative expression of writers and artists in different cultural contexts in contemporary (global) society-bearing witness against cultural and self-amnesia; the trauma of self-exile and the self-exile of trauma.

\section{References}

Alexander, J.; Eyerman, R.; Giesen, B.; Smelser, N.; Sztompka P. (2004). Cultural trauma and collective identity. California: University of California Press. 
Bacon, W. (2006). Journalism as research? Australian Journalism Review, 28(2), 147-157.

Bakhtin, M. (1981). The dialogic imagination: Four essays. In M. Holquist (Ed.) Trans. C. Emerson and M. Holquist. Austin and London: University of Texas Press.

Belau, L. \& Ramadanovic, P. (2002). Topologies of trauma: Essays on the limits of knowledge and memory (contemporary theory). New York: Other Press.

Benson, R. \& Neveu, E. (2005). Bourdieu and the journalistic field. Cambridge: Polity Press.

Brennan, F. (2003). Tampering with asylum: A universal humanitarian problem. St Lucia: University of Queensland Press.

Brinson, S. J. (2002). Aftermath: violence and the remaking of a self. Princeton: Princeton University Press.

Bryman, A. (2002/2004). Social research methods (2nd ed.). Oxford: Oxford University Press.

Bourdieu, P. (2005). The political field, the social science field, and the journalistic field. In Benson, R. and Neveu, E. (Eds.) Bourdieu and the journalistic field. Cambridge: Polity Press.

Bourdieu, P. (2008/1993). The field of cultural production: Essays on art and literature. Cambridge: Polity Press.

Bourdieu, P. \& Wacquant, L.C. (1992). An invitation to reflexive sociology. Chicago: The University of Chicago Press.

Caruth, C. (ed.) (1995). Trauma: Explorations in memory. Maryland: John Hopkins University Press.

Caruth, C. (1996). Unclaimed experience: trauma, narrative and history. Maryland: Johns Hopkins University Press

Coghlan, J.; Minns, J. \& Wells, A. (Eds.) (2005). Seeking refuge: Asylum seekers and politics in a globalising world. Wollongong: University of Wollongong Press.

Gale, P. (2004). The refugee crisis and fear: Popular politics and media discourse. Journal of Sociology, 40(4): 321-339.

Every, D (2008). A reasonable, practical and moderate humanitarianism: the co-option of humanitarianism in the Australian asylum seeker debates. Journal of Refugee Studies, 21(2), 210-229.

Hughes, R. (1986/2003). The fatal shore. London: Vintage.

Human Rights and Equal Opportunity Commission (2004). A last resort? National inquiry into children in immigration detention. Sydney: Human Rights and Equal Opportunity Commission.

Jakubowicz, A. (2002). White noise: Australia's struggle with multiculturalism. In C. Levine-Rasky (Ed.). Working through whiteness: International perspectives. Albany: SUNY Press.

Jandt, F.E. (2007). An introduction to intercultural communication: Identities in global communities (5th edition). California: Sage Publications.

Johnson, J. and Pearson, M. (2008). Australia's media climate: Time to renegotiate control. Pacific Journalism Review, 14(2): 50-72. 


\section{PUBLIC RIGHT TO KNOW}

Kaplan, E.A. (2005). Trauma culture: the politics of terror and loss in media and literature. New Jersey: Rutgers University Press.

Keneally, T. and Scott, R. (Eds.) (2004). Another country: Writers in detention. Sydney: Halstead Press.

Kevin, T. (2004). A certain maritime incident: The sinking of Siev X. Carlton North: Scribe Publications.

Kone, C. (2004/2007) A long road. In Keneally. T., and Scott, R. (Eds.), Another country: writers in detention. Sydney: Halstead Press.

Kramer, L. (1995). Classical music and postmodern knowledge. USA: The University of California Press.

Kramer, L. (2001). Musical meaning: Towards a critical history. USA: The University of California Press.

Kristeva, J. (1974). La révolution du langage poétique. Paris: Editions du Seuil.

Kristeva, J. (1980). Pouvoirs de l'horreur. Paris: Editions du Seuil.

Kristeva, J. (1982). Powers of horror: An essay on abjection. Trans. Leon S. Roudiez. New York: Columbia University Press.

Kristeva, J. (1986). The Kristeva reader. Trans., ed. and intro. by Toril Moi. Oxford: Blackwell.

Van Leeuwen, T. and Kress, G. (2001). Multimodal discourse: The modes and media of contemporary communication. London: Hodder Education.

Leith, D. (2004). Bearing witness: The lives of war correspondents and photojournalists. Milsons Point: Random House.

Leys, R. (2000). Trauma: A genealogy. Chicago: University of Chicago Press.

Liamputtong, P. (2007). Researching the vulnerable: A guide to sensitive research methods. London: Sage Publications.

Marr, D. (2008, April 18-19). Trauma by the boatload. Sydney Morning Herald.

McClary, S., (Ed.) (2002) Feminine endings: music, gender and sexuality. Minneapolis: University of Minnesota Press.

National Union of Journalists (2004/2008). Reporting asylum and refugee issues. Retrieved on 5 October 2007, from www.mediawise.org.uk.

Nochlin, L. (1994). Women, art and power and other essays. London: Thames and Hudson.

Osuri, G. and Banerjee, B. (2004). White diasporas: media representations of September 11 and the unbearable whiteness of being in Australia. Social Semiotics, 14(2), 151-171.

O'Shaughnessey, M. \& Stadler, J. (Eds.) (1999/2006). Media and society: an introduction (3rd edition). Oxford: Oxford University Press.

Pickering, S. (2001). Common sense and original deviancy: news discourses and asylum seekers in Australia. Journal of Refugee Studies. 14(2), 169-189.

Popescu, L. \& Seymour-Jones, C. (Eds.) (2007). Another sky: voices of conscience from around the world. London: Profile Books.

Said, E. W. (1993/1994). Culture and imperialism. New York: Vintage Books.

Schon, D. (1983). The reflective practitioner: how professionals think in action. London: Temple Smith. 
Schon, D. (1987). Educating the reflective practitioner. San Francisco: Jossey-Bass, 1987.

Skilbeck, R. (2005). Persephone's paradox: the author's journey into the Underworld. In Motham, L; Douglas, K.; Dwyer, T.; Walker, S.; Wooler, S.

Skilbeck, R. (2007). The writer's fugue: Musicalization, trauma and subjectivity in the literature of modernity. Unpublished $\mathrm{PhD}$ thesis. Sydney: University of Technology, Sydney.

Skilbeck, R. (2008, February 3). Make art not war. homepagedaily.com .

Skilbeck, R. (2008). Art Journalism and the impact of 'globalisation': new fugal modalities of story-telling in Austral-Asian Writing.' Pacific Journalism Review, 14 (2), 141-161.

Skilbeck, R. (2009, May 3). Refugee writers beyond detention. homepagedaily. com.

Cornelius, M. (Eds.).(2005). Women doing research 2005 conference (pp. 1-10). 1921047-10- 0. Women In Research. Rockhampton: Central Queensland University, http://acquire.cqu.edu.au:8080/vital/access/manager/Repository/ cqu:2263? sort=type

Sydney PEN (2007). Submission to the Human Rights and Equal Opportunity Commission for the Community Services Award. (2004). www.pen.org.au/index Retrieved on 23 September 2007, from www.refugeecouncil.org.au

Warren, C. (2005). Introduction. Turning up the heat: The decline of press freedom in Australia 2001-2005. Sydney: Media Entertainment Arts Alliance.

Watter, C. (2007). Refugees at Europe's borders: the moral economy of care.

Transcultural psychiatry, 44(3), 394-417.

Zand, M.S. (2004/2007). Dream of freedom; The wall; The only hope after God; Visitor; Write an essay about love; Child born in Palestine; Coffin; Drought; I am not crazy; Realpolitik; [it's Night]. In Keneally, T., and Scott, R. (Eds.), Another country. Sydney: Halstead Press.

Zand, M.S. (2003-2005). Australian dream CD. www.stickylabel.com.au

Zand, M.S. (2001). Mohsen CD. www.stickylabel.com.au

Dr Ruth Skilbeck is a lecturer in journalism at the University of Technology, Sydney. Research for this paper was supported by a grant from the Australian Centre for Independent Journalism (ACIJ). Supporters of the project include Sydney PEN and the Writers' in Detention Committee: Dr Rosie Scott, Professor Denise Leith, Kathryn McKenzie and Lesley Carnus at the University of Sydney Centre for Peace and Conflict Studies; A Just Australia; and The Refugee Council of Australia, Oliver Freeman. The author wishes above all to acknowledge Mohsen Soltany Zand and Cheikh Kone for their generosity in discussing their journeys of exile and their writing. ruth.skilbeck@uts.edu.au 